\title{
Envy - an Unwanted, yet Unavoidable and Necessary Emotion
}

\author{
Andrea Milic \\ University of Rijeka, Faculty of Humanities and Social Sciences, Department of \\ Psychology, Rijeka, Croatia
}

\begin{abstract}
Envy is a word signifying an emotion that arises from social comparison and signals that one is outperformed by another person, or group of people, which makes one feel painful inferiority. It originates from the Latin "invidere" which means to "gaze maliciously". Yet, this emotion does not want to be communicated. It is hard to identify or admit it, partly because of a range of other negative emotions, such as hostility, resentment and rejection that accompany envious feelings. Envy may also trigger admiration that motivates one to "do better". However, subjective, historical and philosophical accounts overwhelmingly speak of its negative consequences. Not surprisingly, envy is regarded as a social taboo. Even the traditional scientific community considers envy as a "second class" emotion. It is said that envy does not meet the criteria for basic emotions. Only recently, with the paradigmatic shift in modern evolutionary psychology, a new framework was offered and started shedding light onto the emotion nobody likes to feel, think or talk about. This paper presents a review of theoretical considerations, predictions and empirical results, emerging from a relatively small amount of studies that incited a change in the conceptualization of this unwanted and seemingly inept emotion.
\end{abstract}

Keywords: emotion, envy, social comparison, evolutionary psychology

\section{Introduction}

Out of all emotions in the human repertoire, envy is perhaps the least present in our vocabulary. It signifies an unpleasant, negative emotional response to another person or group of people only because they have/appear to have a superior quality, achievement, status or possession that we desire and wish that they would lack (Smith \& Kim, 2007). Envy is also banned by norms of social behaviour that teach us to be well mannered and happy for the success of others. It is an emotion prohibited by all religions. Merely wishing wrong to another is enough to send one

Andrea Milic, Department of Psychology, Faculty of Humanities and Social Sciences, Sveucilisna avenija 4, 51000 Rijeka, Croatia. E-mail: amilic@ffri.hr 
straight to hell. Furthermore, out of the seven deadly sins ${ }^{1}$, it is only envy that is not fun under any circumstances (Epstein, 2003). Not surprisingly, this highly destabilising emotion is accompanied by a profound feeling of shame. We are notoriously disinclined to acknowledge it even to ourselves (Heikkinen, Latvala, \& Isola, 2003). Therefore we tend to rationalize our episodes or states of envy by resentment against "their lack of qualities" or hostility against their "abundance of pure luck". Shame that accompanies envy originates from at least three sources: the shame of feeling envy and its concomitant sense of inferiority and hostility, the shame of realizing that one is to blame for one's inferiority, and the shame of feeling shame (Smith, 2004).

However, like with every persistent and strong emotional experience, the topic of envy has found its prominent place in philosophy, literature and cinema that portray fictional or real characters driven and absorbed by envy. Biblical warnings through the story of Cain and Abel, Salieri's prototypical fixation on Mozart's talent depicted in Forman's movie "Amadeus", the green-faced Grinch who stole Christmas - all remind us that this emotion can easily overspill into tragedy. Overcome with envy, one is able to sacrifice one's own outcomes to diminish the envied person's relative advantage and experience malicious joy when the envied person suffers (Smith \& Kim, 2007). Even the noble and dignified, the fortunate, famous and wealthy, are not safe from its influence. ${ }^{2}$

Envy is often confused with a range of other emotions, such as hostility, shame, longing (Parrot \& Smith, 1993) that demonstrate its transmutational nature (Smith, 2004). However, empirical results (e.g., Van de Ven, Zeelenberg, \& Pieters, 2009) point out that "pure" envy can be distilled from co-occurring emotions such as admiration and resentment and that one "combination" of emotions may result in benign, and the other in malicious envy.

The cunning nature and design of envy transpires in the semantic field too. MSOffice Word Thesaurus offers synonyms such as: jealousy, greed, bitterness, resentment, spite and desire, although empirical data confirms that all of these emotions have their own specific purpose, as well as distinctive behavioural and biological signatures and should not be confused. Envy is mostly used interchangeably with jealousy or greed but it takes one person for greed, two for envy and three for jealousy. Longing and desire are predecessors of both greed and envy. However, when feeling envy, people feel miserable because they compare their own situation to that of others who are better off, while for greed it is enough to compare

\footnotetext{
${ }^{1}$ Pride, greed, lust, envy, gluttony, wrath, sloth.

${ }^{2}$ E.g., Episode 8/Season II of "The Queen" by Stephen Frears portraying the story of a dinner hosted in 1961 for Jackie and JFK by Queen Elisabeth. According to the anecdotal evidence, Queen Elisabeth felt upstaged by Jackie and engaged in the passive-aggressive catfight. However, this competition with Jackie motivated her to "act out of character" too. During her travel to Ghana, she impressed PM Nkrumah by "forgetting" the protocol and winning popular support.
} 
one's own situation to an imaginary situation of having more (Seuntjes, Van de Ven, Zeelenberg, \& Breugelmans, 2015). Likewise, both envy and jealousy motivate people to undermine rivals, but envy is fuelled by disadvantages against someone who is perceived to have the desired advantages, while jealousy signals the need to ward off threats to valued relationships (Buss, 2013; DelPriore, Hill, \& Buss, 2012). Furthermore, envy and jealousy often co-occur; we may envy the rival in a "love triangle" which could increase our jealousy (Smith \& Kim, 2007).

In some languages there exist two words in order to verbalise the experience of envy. ${ }^{3}$ One word implies positive, benign or constructive envy that feels like admiration. Another implies negative, malicious, destructive envy that feels like hostility with its extreme in "schadenfreude", a German word signifying a pleasure obtained from witnessing another person's misfortune (Van Dijk, Ouwerkerk, Goslinga, Nieweg, \& Galluci, 2006). These two qualitatively different experiences of envy exist even in cultures where only one word represents both types of envy (e,g. see Gershman, 2014). Moreover, while the word jealousy is often used to indicate envy (saying "I am jealous", meaning "I am envious"), it never occurs that the word envy is used to indicate jealousy (saying "I am envious", meaning "I am jealous") (Van de Ven et al., 2009). More recently, Falcon (2015) examined the taxometric properties of envy to examine its latent structure and establish whether the construct can be best defined as categorical or purely dimensional. The study supported the claim that benign envy exists too and that it is distinct from malicious envy.

In addition to its linguistic disguises, there seemed to be not only social but academic prohibition of the concept of envy in place. Schoeck (1969) noted that envy has been repressed by the scholastic community, veiled under misleading titles, or conceptualised narrowly. He referred to the framework of psychoanalytical approaches that focused on unconscious objects of envy 40 years later, Smith and Kim (2007) arrived at similar conclusions: many psychologists have found psychoanalytic focus on envy too narrow to start understanding envy. They noted the same discrepancy: a powerful influence of envy in social interactions and, on the other hand, early stages of psychological research on envy.

Envy has been observed as emerging at about two years of age when mental development enables better comprehension of social interactions and allows for comparison with others. It is hypothesised to be a social, complex, self-conscious emotion (e.g. see Niedenthal \& Ric, 2017). Viewing both pleasant and unpleasant emotions as functional responses to our environment has been commonly accepted by mainstream scientific contributions, from appraisal theories (e.g., Lazarus, 1991) to psychological constructionism (e.g., Lindquist, 2013). However, little consistency

\footnotetext{
${ }^{3}$ E.g. Benijden and Afgunst in Dutch, Zaz Doršć and Zavišć in Polish, Zavist i Jal in Croatian (whereby Zavist may be both benign and malicious, and Jal, rarely in use, stands for malicious only).
} 
has been found in the functional logic of envy. It seems to make no sense at all and may only cause damage, just like an inflamed appendix, a rudimentary "left-over" organ in our evolved bodies.

The overdue breakthrough in understanding this unwanted emotion came about with the evolutionary psychology approach that started deciphering a number of previous, somewhat confusing or counter-intuitive empirical findings regarding human behaviour (e.g. see Confer et al., 2010). Following the proposition that evolution is relevant in every single instance of human behaviour although we may not be aware of it; all psychological mechanisms, including seemingly "useless" emotions, are adaptive, evolved responses to statistically recurrent problems in the competitive arena of natural or sexual selection (Buss, 2005). Focusing on domain specificity, frequency, functionality, and the biological basis of emotions (e.g. see Larsen \& Buss, 2010), researchers have categorized anger, disgust, fear, happiness, sadness, surprise and contempt into the group of basic emotions. According to the traditional evolutionary psychology criteria, emotions are considered as basic if present in other species, each of them solves a specific subset of adaptive problems, and all of them have distinctive and universal facial signals (Ekman, 1992). As we shall see, envy is hypothesised to have evolved due to the necessity of managing social relationships. Its covert nature and lacking of a distinct facial expression expelled it from the category of basic emotions.

A new window with a landscape view on this insufficiently researched emotion opened with a paradigm shift within the evolutionary psychology approach. AlShawaf, Conroy-Beam, Asao, \& Buss (2016) claim that a whole class of emotions have evolved as a result of adaptive problems related to reproductive success, and not necessary survival. For this reason, they had not received deserved attention. However, Alcook's and Dawkin's research (as cited in Al-Shawaf et al., 2016) points out that adaptations promoting an organism's survival at a disadvantage to its overall reproductive success are entirely absent in the behaviours of living species. Taking into account the evolutionary challenges of the contemporary world, Buss (2013) recalibrated criteria for defining basic emotions. Emotions are conceptualised as the finest superordinate programs that compute, adjust and coordinate a number of subprograms, from cognitive to physiological, while solving problems with evolutionary important implications (Cosmides \& Tooby, 2000). With such a paradigmatic shift, emotions that lack distinctive communication signals, are unique to humans and have evolved to solve a broader range of adaptive problems, have finally started earning academic attention. Consequently, Buss (2013) argues that sexual jealousy is also a basic and essential emotion, although it is unlikely to solve problems of survival. What follows is a review of theoretical considerations, predictions and empirical results, emerging from a relatively small amount of studies that incited a change in the conceptualization of this unpleasant, often harmful and seemingly inept emotion. 


\section{Causes, Function and Behavioural Manifestations of Envy}

Envy arises when we compare ourselves unfavourably with others (Smith \& Kim, 2007) and is hypothesized to signal an important strategic interference (Buss, $1989 \mathrm{~b})$ in the on-going social competition over resources. It indicates that we are outperformed by someone who has acquired a desired status, attracted mates or has a possession we want. From early human settlements to the contemporary and global social arena, social comparison has been the most important mechanism to assess where we stand in pursuit of self-important goals. It is an adaptive mechanism, providing information and motivation. However, the feelings that follow can be poisonous (Fiske, 2010). In other words, there is a basic discrepancy between using social comparisons to assess our abilities and using them to maintain an ego enhancing sense of superiority (Smith, 2004). Consequently, schadenfreude may be justifiable for the one experiencing such a socially shameful emotion, because rather than admitting to inferiority, it may satisfy people's concern for a positive self-view and a sense of self-worth (Van Dijk, Ouwerkerk, Wesseling, \& Koningsbruggen, 2011). Therefore, submission, ambition, but also destruction may surface as behavioural responses (Hill \& Buss, 2008). In the environments that generate highly competitive (e.g. see Vidaillet, 2008), or contradicting demands, two basic strategies seem most adaptable: make myself more attractive or make rivals less attractive (Hill \& Buss, 2008). Research suggests that hostile behavioural manifestations prevail; from dislike to even giving up one's highest outcome only to damage at least the reputation of the envied one (Smith \& Kim, 2007). Envy has been found to be frequently connected with the perception of fairness and justice (Johar, 2011), and appraisal patterns of deservingness and control (Van de Ven, Zeelenberg, \& Pieters 2012). People feel more envious hostility toward another individual when they judge the situation that exposed their inferiority as unfair. The more a situation is appraised as undeserved, the more malicious envy will be experienced. However, when the situation is experienced as deserved and controllable, benign envy may be manifested.

The purpose of envy, seen through the glasses of evolutionary logic, becomes more obvious when focusing on its social triggers. Research indicates that envy is directed towards those similar to us in the desired, self-defining domain (e.g. see Smith \& Kim, 2007). Since we perform social comparisons frequently, there is a need to have them done in a quick and efficient manner, with the use of "routine standards" such as close friends (Rütter \& Mussweiler, 2005). Applying an admittedly farfetched, yet indicative "thought experiment", Ramachandran and Jalal (2017) asked participants in their study whether they feel more envious of Bill Gates or of their neighbour that is slightly better off. Contrary to common sense, participants of the study were not interested in the absolute values. They were more envious of the status of their neighbours, even if slightly better off, than that of Bill Gates. Given the nature of evolutionary process, the rule "always do the best you can" does not specify at what point we can relax (Hill \& Buss, 2006) and leaves us 
with an even bigger problem of having to waste all of our resources or admitting that we don't have many at our disposal after all. Therefore, a specific cognitive adaptation in the form of positional bias needs to be adopted so that success is judged in domains that affect fitness in terms of standing relative to one's reference group, our neighbourhood, our work group, perhaps even our family. This evolutionary driven logic works especially when related to important goals (Lazarus, 1991). Results of Salovey and Rodin's (1991) survey of 6482 randomly selected readers of a national magazine indicate the importance of domain as a prerequisite to experience envy. This group of participants rated their popularity among friends, physical attractiveness, wealth and possessions as domains of their higher interest while fame was rated as less important. Results of the subsequent questionnaire in which they registered instances of experiencing envy demonstrated a higher positive correlation with the specified domains of interest. Researchers examining social comparison mechanisms identified another ingredient necessary to trigger envious feelings. We envy similar others who enjoy an advantage in a domain related to our self-worth and when the perception of control over circumstances is low (Testa \& Major, 1990; Van de Ven et al., 2012). However, it is important to note a general principle characterizing various social emotions: we may not envy advantages of the envied because they are personally important to us but merely because they have high societal value (Lange, Blatz, \& Crusius, 2017).

Should our behaviour be guided by evolutionary logic, the closer we get to the critical aspects of evolutionary fitness and reproductive problems, the more we should be prone to experience episodes of envy (Hill \& Buss, 2006). Consequently, envy will need to demonstrate sex differentiation in domains where the sexes have faced qualitatively different but recurrent adaptive problems. This prediction has already been empirically confirmed considering previously puzzling sex differences in experiencing jealousy and aggressiveness (e.g., Buss \& Shackelford, 1997; Campbell, 2011). Examining sex-differentiated positional bias, Hill and Buss (2006) collected data that confirmed evolutionary perspective predictions on gender differences in envy as well. The target of men's and women's envy will be individuals with whom they are in direct resource competition (friends, siblings, co-workers) and more often they will be the same-sexed targets. However, women, in a greater degree than men, prefer a scenario in which they are more attractive than their same-sexed peers and less attractive in absolute terms. Therefore, in the domain of attractiveness, women will be compelled to apply a stronger positional bias. Women will feel more envious than men when their same-sexed friend receives an expensive gift from her romantic partner. Men will envy their peers that have more sexual experience than themselves. Subsequent research confirmed predictions that sex differences in envious responses will be consistent with research on mate preferences from the evolutionary perspective. Same predictable domains will guide these preferences (DelPriore et al., 2012; Hill, DelPriore, \& Vaughan, 2011). Men will feel more envious towards those rivals that are better off for their ability to acquire resources, while women will target youth and physical attractiveness (Buss, 1989a). Gender 
effect was also found in Wobker and Kenning's (2013) experimental study of drivers and outcome of envy in an economic group game. The game was set up in a way that participants were free to choose their strategy while playing the game. In that, what may have worked as an individual's best strategy (personal quest for money/rank/status) was destructive in a group setting. Women took chances to reduce the accumulated wealth of the other players more often than men. However, men were keen on damaging the other players to a higher extent than women. The results are concordant with the prediction that men would be more affected by statusoriented emotions because such behavioural adaptation enhances their evolutionary fitness to collect resources (Hill \& Buss, 2006). Furthermore, studies indicate that envy will more likely turn to schadenfreude when the target of social comparison is of the same gender (van Dijk et al., 2006).

In order to understand why and how envy turns benign or malicious, Lange, Blatz, and Crusius (2017) propose to focus on the different pathways of attainment of the desired status. In "prestige-based" hierarchies, status is based on merit and fairness. Thus, the evolutionary sound behavioural strategy would be to turn the bitter bites of envy into a benign motivation to gain respect by sharing skills, and "passing on" the traits of agreeableness and emotional stability. In "dominance-based" hierarchies, status is based on the outcome of the zero-sum conflict. In such environments, it would be adaptive to develop a chronic dominance strategy fuelled by malicious envy in order to be able to intimidate others and foster subordinates' deference.

The above theoretical and empirical considerations added to the growing debate on whether there is such a construct as the typical envious personality type. In other words, would some people be more susceptible to envy and what in their psychological set-up would make them more prone to envy than others?

\section{Personal Tendency to Envy and How to Measure It}

The evolutionary perspective considers individual differences and variability in personality traits important features of our species that allow us to compete for differential evolutionary relevant outcomes. If selection pressures vary over time or space, as some of them do, then selection can favour different levels of a personality trait in these environments (Buss, 2009). This fitness-relevant diversity (specific abilities, behavioural tendencies, body type, etc.) has a heritable component and it is relatively stable over time. Therefore envy, just as any other emotion, may be considered as an episode/specific, a mood and state/general and as a personal tendency/dispositional (Duffy, Scott, Shaw, Tepper, \& Aquino, 2012). Individual tendency, i.e. one's typical behaviour triggered by upward status comparisons may also depend on other behavioural inclinations; e.g. towards inequity aversion, justice sensitivity and achievement motivation (Lange, Blatz, \& Crusius, 2017). 
Smith, Parrott, Diener, Hoyle, \& Kim (1999) developed the 8-item, selfreported instrument: the Dispositional Envy Scale (DES) that is, amongst a few other scales, used more widely. The scale consists of items measuring a sense of inferiority and frustration (the facets of benign and malicious envy), ill will, and perceptions of injustice (indicative of malicious envy). DES has been found to show good internal consistency with $\alpha=.83-.86$, and re-test reliability over a two-week period, $r=.80$ (Smith et al., 1999). Application of the Brazilian-Portuguese (Milfont \& Gouveia, 2009) and Argentinian (Mola, Saavedra, \& Reyna, 2014) versions of the DES confirmed its good psychometric properties. The scale does not discriminate between two types of envy.

Following findings on two qualitatively different forms of episodic envy, and using the newly developed Benign and Malicious Envy Scale (BeMaS), Lange and Crusius (2015a) demonstrated two independent dimensions of dispositional envy that are related to distinct behavioural consequences. The Dispositional Benign Envy subscale $(\alpha=.85)$ and the Dispositional Malicious Envy subscale $(\alpha=.89)$ showed internal consistency and were not correlated, $r(365)=.01, p=.89$. The DES showed no significant relation with the Dispositional Benign Envy subscale $r(365)=.04, p$ $=.46$, but was significantly correlated with the Dispositional Malicious Envy subscale, $r(365)=.65, p<.001)$. In a set of four studies, and as measured by BeMaS, benign envy predicted and confirmed faster race performance of marathon runners mediated via higher goal setting. Dispositional malicious envy predicted and confirmed race goal disengagement. In the words of BeMaS authors, translated versions of the BeMaS may be an interesting means to test motivational dynamics and cultural differences of dispositional benign and malicious envy.

The existing scales, although through limited use, indicated particular relationships with a number of psychological constructs (see Lange, Blatz, \& Crusins, 2017). Those with a tendency to envy are more likely to be neurotic, disagreeable, insecure, hostile (Smith et al., 1999), ungrateful (McCullough, Emmons, \& Tsang, 2002) and greedy (Seutjens et al., 2015). Furthermore, vulnerable narcissism fuels dispositional envy and the envious suffer from a chronic feeling of inadequacy and low self-esteem (Krizan \& Johar, 2012). However, it must be noted that researchers' choices of scales and conceptual perspectives differ; from measuring general trait envy to measuring specific (benign or malicious) outcomes of emotiongenerative processes. This makes it harder to disentangle individual differences between envy-specific experiences and other related psychological constructs.

Given the importance of domain in experiencing envy, Rentzsch and Gross (2015) developed a Domain-Specific Envy Scale (DSES) that showed good psychometric properties when tested on a German-speaking sample and crossvalidated with an English-speaking sample. The scale significantly positively related to the DES that measures general tendency without differentiating between benign and malicious envy and it was used to confirm a strong positive correlation of 
dispositional envy and lower self-esteem. When re-used three months later, the relationship remained stable.

A relationship of certain health risks and different personality traits has been already established by researchers, in so far that a general framework for personalityhealth research has been proposed (e.g. see Kardum \& Hudek-Knežević, 2002). Initial data sets resulting from the application of the few available dispositional envy scales indicate a negative correlation of envy with well-being measures such as life satisfaction, vitality and subjective happiness (Milfont \& Gouveia, 2009; Mola et al., 2014). A more recent quasi-experimental online study (Appel, Crusius, \& Gerlach, 2015) not only confirmed a positive relationship between depressiveness, lowesteem and envy but provided insights into how depression may intensify envy, specifically when one is facing high and frequent comparison standards on social virtual platforms, such as Facebook.

Finally, a novel study of neural signatures of dispositional envy, perhaps the first of its kind (Xiang et al., 2017), revealed a positive correlation of dispositional envy with grey matter volume in the left dorsolateral prefrontal cortex and superior temporal gyrus. The study offered neurological evidence of the mediating role of emotional intelligence on experiencing and exhibiting envy pointing out how individuals with higher emotional intelligence, and increased ability for emotional regulation, exhibit less envy.

\section{Implications of Envy}

In the last decade, researchers started addressing the apparent imbalance between theoretical and empirical considerations of individual, interpersonal and social implications of envy, although focusing mostly on the envious, rather than on the envied.

Hard evidence, enabled by the fMRI technology, already documented neural mechanisms of envy and its "rewarding" reaction, schadenfreude (e.g. Takahashi et al., 2009). Envy is processed in the medial prefrontal cortex and anterior cingulate cortex, parts of the brain known to integrate emotion and cognition. Hill et al. (2011) also provided initial experimental evidence that envy has not only an affective, but a prominent cognitive component with a functional task. Emotional distress created by envy prompts the envious to employ a set of cognitive/goal oriented strategies: temporarily filter out information that is less relevant to the problem, retrieve a storage of relevant information from memory, focus attention on the source of strategic interference and finally motivate action to prevent future interference (Buss, 1989b). The results indicated that the experience of envy enables people to better focus on information about social targets and enhances memory and ability to correctly recall key data. However, "under the spell of envy" we are also less able or willing to invest efforts in another, unrelated domain. No matter the, admittedly, limited research design (e.g. it was not sex-differentiated), it opened venues for 
further explorations on what other tasks, other than cognitive, envy is likely to coordinate or inhibit.

When we hungrily watch a friend eating pizza, would we envy them more if the pizza was already sliced? Should the evolutionary account be accurate, the intensity of envy would indeed increase with the perceived divisibility of resources and higher expectations of sharing. In other words, we would envy more if the friend's pizza were sliced up (easily divisible) no matter the equal total size of pizza and/or if our friend appears to have no intention of sharing it (whether sliced or not). Three experiments designed by Inoue, Hoogland, Takehashi, \& Murata (2015) confirmed this prediction and offered novel insights into the adaptive function of envy. If "pizza owners" realize that the disadvantaged person is envious, they may be prompted to share in order to avoid the potential negative consequences of being envied. Showing willingness to share resources gives less reason for envy to endure, unless risking to appear ungrateful. While focusing on general envy without dividing it into benign and malicious, the authors rightfully argue that their findings may demonstrate a reason why envy has evolved. Given the variability in the willingness to share resources, envy signifies an adaptive attempt to maximize one's relative share of resources any way possible. Inoue et al. (2015) concluded that while most people believe that envy breeds hatred and should be discouraged, it may ultimately lead to receiving valuable resources and, to an extent, be a necessary evil.

Another study that has examined the relationship between individual differences in social comparisons and destructive emotions and behaviours, ascertained that people who make frequent social comparisons, experienced envy more frequently, and were more likely to lie, blame others and to have unmet cravings (White, Langer, Yariv, \& Welch, 2006). Duffy et al. (2012) studied workrelated consequences of envy in a university hospital where employees and students were assessed by a series of instruments adapted to the team context. Researchers tested whether envy will be a reliable predictor of social undermining. The first study confirmed the prediction that when employees have low social identification with co-workers, the mediated effect of envy on social undermining through moral disengagement will be stronger. The second study demonstrated that the indirect effect of envy on social undermining through moral disengagement is stronger in teams with low team identification and high team undermining norms. Duffy et al. (2012) do not negate that social identification with the closer and more similar ones generates envy, as found by researchers previously. However, the behavioural responses are further shaped by moral disengagement. Without distancing from the otherwise highly socially identifiable target, social undermining would not be easy to perform. Smith and Kim (2007) found a strong positive correlation between prejudice and envy, which may be another strategy of distancing from the target. When examining antecedent emotions for schadenfreude, Hareli and Wiener (2002) provided evidence that other emotions, independent of envy, may give rise to experiencing schadenfreude. Yet, given that envy and pride often co-occur (Lange 
\& Crusius, 2015b), it is conceivable that rather than admitting one's own inferiority, it may be easier to mask envious feelings with dislike and anger against a target, and thus, justify schadenfreude.

Although organizational settings proclaim high standards of politeness, researchers have found that envy causes social loathing and withdrawal behaviours (Duffy \& Shaw, 2000). In that, high performers are more likely to be targets of victimization (Kim \& Glomb, 2014). Starting from first systematic studies of envy in the group settings (Vecchio, 1995, 1999), results indicate that envy triggers behavioural responses such as sabotaging the rival's work, back-stabbing and harassment.

However, some adaptive correlates of benign envy have also been identified, such as tendency to set personal standards (Rentzsch \& Gross, 2015) and an increase of creativity (Ierides, 2014). Therefore more research is needed to explore how the overwhelmingly negative effects can be mitigated.

Effects of envy, as predicted by evolutionary logic, have been found across industries and in qualitatively different relationships. Van de Ven et al. (2011) examined consumer behaviour and found that willingness to pay a premium for products is derived from their envy. Crusius and Mussweiler's (2012) experimental data demonstrates that envy affects not only buying behaviours but also more basic behavioural outputs: approach and avoidance. After being exposed to an envy provoking situation (wanting what another possesses), participants' self-control ability was also reduced by experimental manipulation. Under these conditions, participants demonstrated an impulsive behavioural tendency to approach the envied target, disregarding social norms that promote restraint. Another study demonstrated that poor relationships between leaders and employees lead to higher levels of episodic envy in employees which then reduced their work engagement and induced social undermining behaviours (Chin-Yi \& Lazatkhan, 2017; Kim, Jung, \& Lee, 2013). Even friendships have been found to be affected by envious feelings. CoboReyes \& Jimenéz's (2012) experimental games demonstrated that people not only care about their payoffs but have preferences about the earnings of others. Surprisingly, the results show that strangers coordinate more frequently in order to reach an efficient gain equilibrium than friends.

One of the rare empirical studies of the effects of envy on the envied included a cross-cultural sample of European American and Spanish participants. Rodriques Mosquera, Parrott, \& Mendoza (2010) found that being envied has both positive (increased self-confidence) and negative consequences (fear of ill will from others). What is also indicative was the finding that being envied had more positive and more negative psychological and relational consequences among those participants who were achievement-oriented (European Americans) than among participants who were oriented to cooperation and interpersonal harmony (Spanish).

Considering the initial empirical data on individual, interpersonal and social implications of envy, more of an effort should be made to identify which personal 
and environmental constraints may affect our envious responses. When one envies their neighbour's bigger house (as expressed by Hill \& Buss, 2008), why do some of us choose to work harder to get the desired advantage, some chose to move to a different neighbourhood, while some decide to devalue and even destroy the neighbour's home? The scientific community has no conclusive answers as of yet.

\section{Methodological Choices and Challenges in the Research of Envy}

A range of experimental, quasi-experimental, correlational, psychometric and neuroimaging methodological solutions are available to scientists nowadays to elicit and measure emotions (e.g. see Niedenthal \& Ric, 2017). However, researchers face particular challenges with emotions that people are reluctant to admit.

When completing the self-reporting scales, participants may underreport their feelings. Smith and Kim (2007) suggest that this problem may be partially addressed by items designed to assess reactions related to envy without containing the actual word (such as: "It somehow does not seem fair, some people seem to have all the talent"). In use of psychometric instruments, they suggest, envy needs also be placed among filter items to distract participants from the actual focus. Reliable and valid instruments of dispositional envy may, indeed, be useful to shed a correlational light to a wide range of problems that are currently not seen as envy-related. One such example is eating disorders with a possible source in attraction envy as suggested by Rentzsch and Gross (2015). Clearly, more research is needed to ascertain specific contributions of psychometric instruments designed to measure a dispositional tendency of envy. They are still in the early stages of development.

Smith and Kim (2007) provided an example of why researchers studying envy cannot ignore the problems of awareness and accurate reporting and offer possible solutions. A number of studies have shown that envy creates conditions for schadenfreude. However, some follow-up studies did not support this finding because of failing to create actual envy. Instead of using target persons who are perceived as real, some researchers asked participants to imagine reactions to hypothetical situations and failed to provide reliable data. Also, researchers need to make sure which aspects of envy are being measured.

A way to bridge the difficulty with awareness and self-reporting is measuring envy in indirect ways. Although scarce, the existing empirical studies offer a range of simple, yet effective methodological and procedural solutions; the use of recalls of emotional memories, social interaction, interaction in a laboratory, emotions occurring in a real-time and quasi-experimental design. Salovey and Rodin's (1991) survey of 6482 readers of the journal "Psychology Today" demonstrated caution that needs to be taken in correlational research. First, they used a cover story to convince participants that the focus of the research is on issues unrelated to envy. Being aware that their sample may compromise the generalization of findings, they repeated the survey on a more conventionally sampled group from the local community. In order 
to examine correlations between domain importance, self-esteem, envy and jealousy they made use of experienced situations, rather than hypothetical. Although statistical significance has been found and the reliability of measured construct was high, the unbiased data analysis led the scientists to note that factors other than those measured could also contribute to the intensity of jealousy and envy.

Fiske (2010) explored the interpersonal dynamic of social status divides caused by societal comparisons. The focus was on the dynamics of "envy up" ("I wish I had what you have", implying "And I wish you did not have it") and "scorn down" ("You are unworthy of my attention, but I know you are down there somewhere"). The researchers used a variety of methods; questionnaires, psychometrics, response time, electromyography and neuroimaging. First, an online survey has been administered to an adult sample that viewed a series of photographs from the SCM quadrants. ${ }^{4}$ Each target was linked to positive/neutral/negative every-day events such as "An elderly woman ate a good sandwich" or "A drug addict yawned twice in a row". Participants rated each person-event pair: "If I saw this happening in real life it would make me feel" $(1=$ extremely bad, $10=$ extremely good $)$. The envied groups received the least positive reactions to their good events and the least negative reactions to their bad events, compared with all other groups and a pre-test baseline. Since these were hypothetical situations, the zygomaticus major (ZM/the cheek smile muscles) was measured by facial electromyography (EMG) in parallel. The ZM activated more for negative events than for positive ones only for envied out-group members. Fiske noted: "People can't help smiling a little when an investment banker steps in dog poo". Furthermore, Fiske (2010) summarised another study that demonstrated the potential of laboratory experiments even though a real-time social exchange is excluded. In this experiment, participants were expected to work for a prize in collaboration with one peer. Pairs differed in their expert knowledge necessary to complete the tasks. They were competing with another expert that worked independently on the same task. Paired participants attended more to the person on whom their outcomes would depend (a more knowledgeable expert). At the same time, the brain's social-cognition network (mPEC) activation was monitored. It activated particularly strongly to surprising information (expectancy-inconsistent) but only for the expert on whom their outcomes depended (a person in a pair who controlled valued resources), not for the independent expert. Admitting that research needs to go beyond comparison mechanisms, Fiske concluded that upward comparison could activate social cognition adaptively. Moreover, empathy and outcome dependence appeared as mediators that can be used as possible cures of unfavourable social comparison before it turns to destructive envy.

Unlike in previous studies whereby videotaped interactions were used (e.g. see Smith et al., 1999), researchers recently started exploiting social media both as a

\footnotetext{
${ }^{4}$ Envy, disgust, pity, pride.

${ }^{5}$ Ames \& Fiske (2010; according to Fiske, 2010).
} 
methodological tool and a potential source of envy. In their quasi-experimental study that examined how depression can intensify envy, Appel et al. (2015) created fake Facebook profiles (attractive and non-attractive) and presented them to depressed and non-depressed individuals. As predicted, depressed individuals reported a higher degree of envious feelings, especially after reviewing attractive profiles. Regardless of the experimental condition, the research provided controlled comparison standards to assess virtual social behaviour. However, due to the convenient sampling measures, only $15 \%$ of participants were male and gender effects could not be investigated.

Hill et al. (2011) activated envy through a written guided imagery procedure using the Qualtrics experimental software. Participants were told they would be part of an experiment that explores how individual differences and the type of media affect emotional responses to social information. After completing distraction tasks, participants observed two target interviews with same-sex experiment assistants, one interview lacking the information that could prime envy, another inducing envy. The experimental group was asked to write about occasions that prompted envy. The results showed that participants spent more time examining fictitious interviews with targets towards which they reported feeling most envious. They were also able to better recall information from interviews with their most envied targets.

In order to examine what types of advantages are most likely to evoke envy and whether the domains will be sex-differentiated, DelPriore et al. (2012) created an online autobiographical narrative study involving 418 participants and found that frequency with which each sex cited specific domains of competitive advantage differed in ways consistent with an evolutionary account of envy. Women cited their rivals' attractiveness as a source of envy more frequently than men did, while men cited their rivals' greater access to financial resources and athletic ability more than women. The study was designed to serve as an exploratory analysis and it provided additional data on predicted sex differences in envy (chastity, status and prestige, athletic talent). However it was conducted on college-aged participants.

In addition to the use of recollections of actual experiences and emotional narrative methodology, scientists turned to behavioural observations. In their field study of bank employees, Schaubroeck and Lam (2004) observed invidious reactions of workers (whose promotions were rejected) towards promotees. As well as a survey that was administered to all tellers in 43 work units with granted anonymity, the bank provided contextual information to researchers (previous performance data and performance sheets after a few months had passed from an unfavourable promotion). The study revealed that levels of envy differed among rejectees depending on their promotion expectation and initial perception of being similar to the person who was promoted. Moreover, five months after the event, the envious promotion rejectees improved their performance more than their less envious counterparts. Researchers speculated that this could be a result of stronger motivation derived from their envious state. Given that the research sample consisted predominantly of women of 
Chinese ethnic origin, these relationships would need to be tested in diverse settings and to account for gender/cultural differences in order to confirm their external validity. Also, it is not certain that performance reports reflected the objective improvement at work.

Following the proposition that group settings in general can produce envious hostility (e.g. Smith \& Kim, 2007), Duffy and Shaw (2000) researched small work groups and provided initial longitudinal results that indicate that absenteeism is indirectly related to self-reported envy and that envy will be positively related to the increase in social loathing and a decrease in group cohesion. Another study (Duffy et al., 2012) collected data from employees at a university hospital on two occasions, eight months apart whereby the chosen scales were utilised to reveal a relationship between envy, social identification, moral disengagement and social undermining. Control variables included age, gender and tenure. Researchers performed thorough response bias checks, measurements assessment and ensured a good model fit. However, it is important to note that the average age of the hospital employees was 37 and the sample was $77 \%$ female.

It is safe to conclude that, while studies in different environments are emerging (e.g. Heikkinen et al., 2003), more studies of real group and organizational environments are necessary to ensure a broader sample size.

Cobo-Reyes and Jimenéz (2012) demonstrated that envy can be efficiently studied by elicitation of latent social networking in an experimental setting. Focusing initially on the phenomenon of social distancing, they found that pairs of strangers, playing a competitive coordination game, reach a more efficient outcome than pairs of friends. Another experimental study (Wobker \& Kenning, 2013) expanded the organizational context to economic decision-making by using the gaming procedure with real money and possible gain. In the first phase, participants played a winnertake-all game to set up unequal gain. The observation phase followed, in which the actual behaviour of participants was scrutinised while they were given an option to reduce the balance of other players. Anonymity of decisions, neutral wording of instructions and distractor tasks ensured that the experiment was framed not to draw attention to the real focus of the study. The results demonstrated that envy predictably affected decisions to reduce the balance of other players. Yet, 2/3 of players did not, in fact, do so, although showing high scores on the measured drivers of destructive envy behaviour. Further studies would, therefore, need to focus on what affects this choice to regulate and translate the experienced envy into actual behaviour? For the sake of methodological decontamination, complete contextual information would need to be captured in possible replicas of this research. As admitted by researchers, in this instance, participants' awareness whether they would or would not need to cooperate with another player in future was not accounted for.

The few examples above are meant to illustrate that, despite currently limited and unsteady empirical results, the pathways for suitable methodological solutions have been set out. Both experimental and actual interactions would benefit from 
involving larger sample sizes, opposite-sex targets, different environments and age groups, reliable measures and procedures that would minimize confounding results. Self-reports are particularly problematic in the study of envy. Hypothetical situations may not provoke genuine reactions, while quasi-experimental settings are hard to control. Finally, because of its capacity to disguise into a range of other emotions, a more holistic approach would need to be taken in future studies. A way to do this is to triangulate psychometric findings, surveys and behavioural observations. Moreover, neuropsychological research (that enables monitoring brain/bodily reactions to emotions and behavioural choices that follow specific emotions) has already shown its potential (e.g., Xiang et al., 2017).

\section{Conclusion}

Thus far, envy has been a topic of curious fascination for philosophers, historians and artists. While significant theoretical considerations exist, science has not yet offered substantial empirical data that would allow understanding all of the facets of this highly volatile and disturbing emotion. However, a promising framework to study "second class" emotions, including envy, has been offered (e.g. see Al-Shawaf et al., 2016). Initial empirical results speak in favour of the modern evolutionary perspective that generates novel hypotheses considering the diversity of adaptive problems emotions are designed to solve. According to this framework, emotions are seen as superordinate programs that coordinate a range of cognitive, perceptual and communication tasks enabling optimal responses to the demands of our environments and situations. No matter how painful it feels and how maladaptive it seems, envy is then yet another basic key on the main coordination switchboard that activates important programs and without which we may end up clueless, disoriented and demotivated. Yet, it is considered a social taboo for a reason.

Since envy arises from social comparison, it seems more important than ever to address this insufficiently researched emotion. Today's modern society, of "winners and losers" and imposed definitions of "success" blasting through the social media, may provoke evolutionary pangs of unknown magnitude. It may make us believe we all struggle for the same scarce resources. It may make us think that the definition of personal success is the same for all. It is possible that such a global and highly competitive environment fosters envy, but leaves us "dry" of its adaptive function. The signal that envy is sending us is not deciphered in a functional manner, partly because we tend to ignore it. The more we envy, the more we deny it. Neglected as such, envy turns into an exaggerated behavioural response or transforms into coverup emotions.

This review attempted to demonstrate that the evolutionary psychology perspective does justice to the emotion of envy. Without it, envy wouldn't make sense. How important it would be to understand the psychological mechanisms of 
envy is perhaps best expressed by Hill and Buss (2008, p. 68): "Rather than coping with envy, the individual is solving the problem that envy has alerted them to fix. Just as the best course of action to remedy a toothache is to remove the decay (rather than developing coping techniques to deal with the pain), the best way to fix envy is to solve the adaptive problem that it is signalling needs to be solved." Systematic empirical research of this emotion is necessary, as much as we are reluctant to deal with it and as much as we cannot avoid experiencing it at times.

\section{References}

Al-Shawaf, L., Conroy-Beam, D., Asao, K., \& Buss, D. M. (2016). Human emotions: An evolutionary psychological perspective. Emotion Review, 8(2), 173-186.

Appel, H., Crusius, J., \& Gerlach, A. L. (2015). Social comparison, envy and depression of Facebook: A study looking at the effects of high comparison standards on depressed individuals. Journal of Social and Clinical Psychology, 34(4), 277-289.

Buss, D. M. (1989a). Sex differences in human mate preferences: Evolutionary hypotheses testing in 37 cultures. Behavioral and Brain Sciences, 12, 1-49.

Buss, D. M. (1989b). Conflict between the sexes: Strategic interference and the evocation of anger and upset. Journal of Personality and Social Psychology, 56, 735-747.

Buss, D. M. (2005). The handbook of evolutionary psychology. New Jersey: John Wiley \& Sons.

Buss, D. M. (2009). How can evolutionary psychology successfully explain personality and individual differences?. Perspectives on Psychological Science, 4(4), 359-366.

Buss, D. M. (2013). Sexual jealousy. Psychological Topics, 22(2), 155-182.

Buss, D. M., \& Shackelford, T. K. (1997). Human aggression in evolutionary psychological perspective. Clinical Psychology Review, 17(6), 605-619.

Campbell, A. (2011). Sex differences in impulsivity: A meta-analysis. Psychological Bulletin, 137, 97-130.

Chin-Yi, S., \& Lazatkhan, J. (2017). Effect of leader-member exchange on employee envy and work behaviour moderated by self-esteem and neuroticism. Journal of Work and Organizational Psychology, 33, 69-81.

Cobo-Reyes, R., \& Jimenéz, N. (2012). The dark side of friendship: Envy. Experimental Economics, 15(4), 547-570. doi:10.1007/s10683-012-9313-0

Confer, J. C., Easton, J. A., Fleischman, D. S., Goetz, C. D., Lewis, D. M. G., Perilloux, C., \& Buss, D. M. (2010). Evolutionary psychology: Controversies, questions, prospects, limitations. American Psychologists, 65(2), 110-126.

Cosmides, L., \& Tooby, J. (2000). Evolutionary psychology and the emotions. In M. Lewis, \& J. M, Haviland-Jones (Eds.), Handbook of emotions (pp. 91-115). New York: Guilford. 
Crusius, J., \& Musswelier, T. (2012). When people want what other have: The impulsive side of envious desire. Emotion, American Psychologists Assotiation, 12(1), 142-153.

DelPriore, D. J., Hill, S. E., \& Buss, M. D. (2012). Envy: Functional specificity and sexdifferentiated design features. Personality and Individual Differences, 53, 317-322.

Duffy, M. K., \& Shaw, J. D. (2000). The Salieri Syndrome: Consequences of envy in groups. Small Groups Research, 31(3), 3-23.

Duffy, M. K., Scott, M. K., Shaw, J. D., Tepper, B. J., \& Aquino, K. (2012). A social context model of envy and social undermining. Academy od Management Journal, 55(3), 643666.

Ekman, P. (1992). An argument for basic emotions. Journal of Cognition and Emotion, 6(34), 169-200.

Epstein, J. (2003). Envy, the seven deadly sins. New York: Oxford University Press Inc.

Falcon, R. G. (2015). Is envy categorical or dimensional? An empirical investigation using taxometric analysis. Emotion, American Psychologists Association, 15(6), 694-698.

Fiske, S. T. (2010). Envy up, scorn down: How comparison divides us. Journal of Personality and Social Psychology, 58, 832-843.

Gershman, B. (2014). The two sides of envy. Journal of Economic Growth, 19(4), 407-438. doi:10.1007/s10887-01409106-8

Hareli, S., \& Weiner, B. (2002). Dislike and envy as antecedents of pleasure at another's misfortune. Motivation and Emotion, 26(4), 257-277.

Heikkinen, E., Latvala E., \& Isola, A. (2003). Envy in a nurse education community. Journal of Nursing Students, 40(3), 259-268.

Hill, S., \& Buss, D. M. (2006). Envy and positional bias in the evolutionary psychology of management. Managerial and Decision Economics, 27(2/3), 131-143.

Hill, S. E., \& Buss, D. M. (2008). The evolutionary psychology of envy. In R. H. Smith (Ed.), Series in affective science. Envy: Theory and research (pp. 60-71). New York: Oxford University Press.

Hill, S. E., DelPriore, D. J., \& Vaughan, P. W. (2011). The cognitive consequences of envy: Attention, memory and self-regulatory depletion. Journal of Personality and Social Psychology, 101(4), 653-666.

Ierides, E. A. (2014). Benign envy and creativity in the workplace. (Unpublished dissertation). Faculty of Chicago School of Professional Psychology, ProQuest.

Inoue, Y., Hoogland, C. E, Takehashi, H., \& Murata, K. (2015). Effects of resource divisibility and expectations of sharing on envy. Motivation and Emotion, 39(6), 961972. doi:10.1007/s11031-015-9498-6

Johar, O. (2011). What makes envy hostile: Perceived injustice or a frustrated search for an explanation? (A thesis submitted in partial fulfilment of the requirements for the degree of Master of Science). Iowa State University. 
Kardum, I., \& Hudek-Knezevic, J. (2002). Relationships between five-factor personality traits and specific health-related personality dimensions. International Journal of Clinical and Health Psychology, 12(13), 373-387.

Kim, E., \& Glomb, M. T. (2014). Victimization of high performers: The roles of envy and work group identification. Journal of Applied Psychology, 99(4), 619-634.

Kim, S. Y., Jung, D., \& Lee, J. S. (2013). Service employees deviant behaviors and leadermember exchange in context of dispositional envy and dispositional jealousy. Service Business, 7(4), 583-602. doi:10.1007/s11628-012-0174-6

Krizan, Z., \& Johar, O. (2012). Envy divides the 2 faces of narcissism. Journal of Personality, 80(5), 1415-1451. doi:10.1111/j.1494.2012.00967

Lange, J., Blatz, L., \& Crusius, J. (2017). Dispositional envy: A conceptual review. In V. Zeigler-Hill \& T. K. Shackelford (Eds.), SAGE Handbook of personality and individual differences (pp. 424-440). Thousand Oaks, CA: SAGE.

Lange, J., \& Crusius, J. (2015a). Dispositional envy revisited: Unravelling the motivational dynamics of benign and malicious envy. Personality and Social Psychology Bulletin, 41, 284-297.

Lange, J., \& Crusius, J. (2015b). The tango of two deadly sins: The social-functional relation of envy and pride. Journal of Personality and Social Psychology, 109(3), 453-472.

Larsen, R. J., \& Buss, D. M. (2010). Personality psychology. New York: McGraw Hill.

Lazarus, R. S. (1991). Emotion and adaptation. NY: Oxford University Press.

Lindquist, K. A. (2013). Emotions emerge from more basic psychological ingredients: A modern psychological constructionist model. Emotion Review, 5(4), 356-368. doi:10.1177/ 17540739134489750

McCullough, M. E., Emmons, R. A., \& Tsang, J. A. (2002). The grateful disposition A conceptual and empirical topography. Journal of Personality and Social Psychology, $82,112-127$.

Milfont, T. L., \& Gouveia, V. V. (2009). A capital sin: Dispositional envy and its relations to wellbeing. Interamerican Journal of Psychology, 43, 547-551.

Mola, D. J., Saavedra, B. A, \& Reyna, C. (2014). Evidence of reliability and validity of dispositional envy scale in Argentinian samples. International Journal of Psychological Research, 7(1), 73-80.

Niedenthal, P. M., \& Ric, F. (2017). Psychology of emotion. New York: Rutledge.

Parrott, W. G., \& Smith, R. H. (1993). Distinguishing the experiences of envy and jealousy. Journal of Personality and Social Psychology, 64, 906-920.

Ramachandran, V. S., \& Jalal, B. (2017). The evolutionary psychology of envy and jealousy. Frontiers in Psychology, 8. doi:10.3389/fpyg/2017.01619

Rentzsch, K., \& Gross, J. J. (2015). Who turns green with envy? Conceptual and empirical perspectives on dispositional envy. European Journal of Personality, 29, 530-547. doi:10.1002/per.2012 
Rodriguez Mosquera, P. M., Parrott, W. G., \& de Mendoza, A. H. (2010). I fear your envy, I rejoice in your coveting: On the Ambivalent Experience of Being Envied by Others. Journal of Personality and Social Psychology, 99, 842-854.

Rütter, K., \& Mussweiler, T. (2005). Bonds of friendship: Comparative self-evaluations evoke the use of routine standards. Social Cognition, 23, 137-160.

Salovey, P., \& Rodin, J. (1991). Provoking jealousy and envy: Domain relevance and selfesteem threat. Journal of Social and Clinical Psychology, 10, 395-413.

Schaubroeck, J., \& Lam, S. S. K. (2004). Comparing lots before and after: Promotion rejectees invidious reactions to promotes. Organizational Behaviour and Human Decision Processes, 94, 33-47.

Schoeck, H. (1969). Envy, A theory of social behaviour. New York: Liberty Fund Inc.

Seuntjes, T., van de Ven, N., Zeelenberg, M., \& Breugelmans, S. M. (2015). Dispositional greed. Journal of Personality and Social Psychology, 108, 917-933.

Smith, R. H. (2004). Envy and its transmutations. In L. Z. Tiedens \& C. W. Leach (Eds.), The social life of emotions (pp. 43-63). Cambridge, UK: Cambridge University Press.

Smith, R. H., \& Kim, S. H. (2007). Comprehending envy. Psychological Bulletin, 133, 4664.

Smith, R. H., Parrott, W. G., Diener, E. F., Hoyle, R. H., \& Kim, S. H. (1999). Dispositional envy. Personality and Social Psychology Bulletin, 25, 1007-1020.

Takahashi, H., Kato, M., Matsuura, M., Mobbs, D., Suhara, T., \& Okubo, Y. (2009). When your gain is my pain and your pain is my gain: Neural correlates of envy and schadenfreude. Science, 323, 937-939.

Testa, M., \& Major, B. (1990). The impact of social comparison after failure: The moderating effect of perceived control. Basic and Applied Social Psychology, 11, 205-218.

Van de Ven, N., Zeelenberg, M., \& Pieters, R. (2009). Leveling up and down: The experiences of benign and malicious envy. Emotion, 9, 419-429.

Van de Ven, N., Zeelenberg, M., \& Pieters, R. (2011). The envy premium in product evaluation. Journal of Consumer Research, 37(6), 984-998.

Van de Ven, N., Zeelenberg, M., \& Pieters, R. (2012). Appraisal patterns of envy and related emotions. Motivation and Emotion, 36(2), 195-204.

Van Dijk, W. W., Ouwerkerk, J. W., Goslinga, S., Nieweg, M., \& Galluci, M. (2006), When people fall from grace: Reconsidering the role of envy in schadenfreude. Emotion, 6, 156-160.

Van Dijk, W. W., Ouwerkerk, Y. W., Wesseling, Y. M., \& van Koningsbruggen, G. M. (2011). Towards understanding pleasure at the misfortune of others: The impact of selfevaluation threat on schadenfreude. Cognition \& Emotion, 25(2), 360-368.

Vidaillet, B. (2008). Workplace envy. London: Palgrave MacMillan. 
Vecchio, R. P. (1995). It's not easy being green: Jealousy \& envy in the workplace. Research in Personnel and Human Resources Management, 13, 201-244.

Vecchio, R. P. (1999). Jealousy and envy among health care professionals. In P. LeBlanc, M. Peters, A. Bussing, \& W. Schauefli (Eds.), Organizational psychology and health care (pp. 121-132). Munich: Verlag.

Vecchio, R. P. (2005). Explorations in employee envy: Feeling envious and feeling envied. Cognition and Emotion, 19, 69-81.

Vecchio, R. P. (2007). Cinderella and Salieri in the work-place: The envied and the envier. In S. W. Gilliland, D. D. L. Steiner, \& D. Skarlicki (Eds.), Managing social and ethical issues in organizations (pp. 109-134). Charlotte, NC: Information Age.

Xiang, Y., Zhao, S., Wang, H., Wu, Q., Kong, F., \& Mo, L. (2017). Examining brain structures associated with dispositional envy and the mediation role of emotional intelligence. Scientific Reports, 7. doi:10. 1038/srep39947

White, J. B., Langer, E. J., Yariv, L., \& Welch, J. C. (2006). Frequent social comparisons and destructive emotions and behaviours: The dark side of social comparison. Journal of Adult Development, 13(1), 36-44. doi:10.1007/s10804-006-9005-0

Wobker, I., \& Kenning, P. (2013). Drivers and outcome of destructive envy behavior in an economic game setting. Schmalenbach Business Review, 65(2), 173-194.

\title{
Zavist - neželjena, ali neizbježna i potrebna emocija
}

\begin{abstract}
Sažetak
Zavist je emocija koja proizlazi iz usporedbe s drugima i upućuje na to da je netko bolji od nas u nečemu te donosi osjećaj bolne inferiornosti. Riječ potječe od latinske riječi "invidere", što znači "zlobno promatrati". Ipak, ta emocija često se prikriva. Teško ju je prepoznati ili priznati, djelomično stoga što osjećaj zavisti prate mnoge druge negativne emocije poput neprijateljstva i odbojnosti. No zavist može izazvati i divljenje, koje nas motivira da budemo uspješniji. Međutim, subjektivna iskustva, povijesni i filozofski zapisi svjedoče o mahom negativnim posljedicama zavisti, stoga ne čudi što se zavist smatra društvenim tabuom. Čak i tradicionalni znanstveni krugovi proglašavaju zavist "drugorazrednom emocijom", odnosno navode da se zavist ne ubraja u osnovne emocije. Tek je nedavno, zahvaljujući paradigmatskom okretu unutar moderne evolucijske psihologije, ponuđen nov okvir koji omogućava bolje razumijevanje ove emocije, koju nitko ne voli osjećati, razmišljati ili razgovarati o njoj. Ovaj rad predstavlja pokušaj pregleda teoretskih razmatranja, predikcija i empirijskih rezultata proizašlih iz relativno malog broja istraživanja koja su izazvala promjenu $u$ konceptualizaciji ove neželjene i naizgled beskorisne emocije.
\end{abstract}

Ključne riječi: emocija, zavist, društvena usporedba, evolucijska psihologija

Primljeno: 16.9.2018. 